\title{
Quantitative Analysis of Nutrition and Health Messages in Indian Print Media
}

\author{
Mekam Maheshwar ${ }^{*}$, Dharmapuri Raghunatha Rao
}

Extension \& Training Division, National Institute of Nutrition, Hyderabad, India

\begin{abstract}
Mass media should be considered as a tool that may influence behaviour of the community. How far mass media, particularly the print media in India is catering the needs of the readers with health and nutrition information? Is the quantity of the health and nutrition information is same or varies between English and regional newspapers? To answer these questions, a quantitative analysis was conducted on English (The Hindu) and Telugu (Eenadu) newspapers pertaining to nutrition and health messages during the month of February, 2010. The percentage of space occupied by health topics in both the newspapers put together was $2.30 \%$. For nutrition topics even less than $1 \%$ space was provided. Indian print media's contribution in dissemination of health and nutrition information is meager. Quantity of health and nutrition information catered by regional language daily is less than the English newspaper. Regional language newspaper readers are mostly consist of economically backward and prone to undernutrition. This segment was not supplied with adequate amount of information on nutrition. Regularity to be followed in publishing health and nutrition news in regional newspapers.
\end{abstract}

Keywords Media Influence, Newspapers, Readers' Behaviour, Nutrition/Health Messages

\section{Introduction}

Newspapers play a major role in disseminating knowledge on various aspects of information relevant to the community[1]. Almost all dailies and popular magazines do publish educative articles on various subjects like Health including nutrition, legal matters, science, business, fashion, women problems, career etc. Newspapers are an important source of health and nutrition information for many readers[2-7]. Leading newspapers give exclusive columns in which experts provide answers to the queries of individual readers on the above subjects. These answers also serve as solutions to many other readers facing similar problems.

\subsection{Mass Media Influence}

Mass media should be considered as a tool that may influence behaviour of the community[8]. India is the biggest newspaper market in the world with 107 million daily sales[9]. Science communication in the developing world like India plays a crucial role in overall progress of the country[10]. How far mass media, particularly, the print media in India is catering to the needs of the readers with health and nutrition information? Is the quantity of the health and nutrition information is same or varies between English and regional newspapers? In order to answer these questions, a quantitative analysis was conducted on health and nutrition

* Corresponding author:

maheswarnin@yahoo.com (Mekam Maheshwar)

Published online at http://journal.sapub.org/phr

Copyright (C 2012 Scientific \& Academic Publishing. All Rights Reserved messages appeared in Indian print media.

Telugu is the largest spoken language among all regional languages in India[11] and also predominant language of the Andhra Pradesh State, one of the South Indian provinces with a population of about 80 millions. Therefore, in the present study, a comparative analysis was conducted between English and Telugu dailies.

\section{Objectives}

To analyze overall coverage of nutrition and health related reports in leading newspapers of India published from Hyderabad, India and to compare quantitative contribution of English and Telugu dailies pertaining to nutrition and health messages.

\section{Method}

Leading daily newspapers of India[12] namely, The Hindu (English) and Eenadu (Telugu) were selected for the study. Comparison was made between these newspapers during the month of February, 2010 pertaining to the news reports published on nutrition and health. Each newspaper was screened date-wise for the study period. Total number of pages of each newspaper was counted including supplementary pages viz., metro plus, young world, property plus of The Hindu and district supplementary pages of Eenadu.

\subsection{Including \& Excluding Criteria}

Actual space available for all types of news and articles 
was worked out. Space occupied by all types of advertisements, television programmes schedules, stock market index, weather reports, cross-word puzzles etc was deducted from the total number of pages to arrive at number of news pages. Unless nutrition or health benefits are emphasized, recipe preparation columns were not taken into consideration for the study. Extent of space for educative news or article or features on health and nutrition topics was measured (including photos and graphs, if any) on column centimeter basis.

Percentage of space provided for health and nutrition topics against total number of pages covering overall news and articles were computed for each newspaper. Health and nutrition related articles published on front page and editorial page if any, were also been identified. A table figuring all the above computations and graphs was prepared for on-hand comparison. For this study, a health or nutrition report was defined as "an information, which would benefit the reader if he/she adopts or practice in terms of health and nutrition".

\section{Results}

A total number of 92 reports on health and 34 messages on nutrition were appeared in The Hindu and Eenadu during the study period. Of which, The Hindu published 45 reports on health and 21 on nutrition, whereas, Eenadu published 47 reports on health and only 13 reports on nutrition (table-1).
The percentage of space occupied by health topics in both the newspapers put together was $2.30 \%$. For nutrition topics even less than $1 \%$ space was provided in these newspapers. In The Hindu, of the total news space available, only $1.01 \%$ was allotted to health reports and $0.67 \%$ to nutrition messages.

In Eenadu, though the percentage of space for health topics was $1.29 \%$ (which is more than The Hindu), nutrition reports got only $0.32 \%$ space.

\subsection{More Visuals}

Eenadu published more number of visuals along with news on both nutrition and health topics (Figure 1 and 2). During the study period Eenadu published a total number of 71 visuals along with various health and nutrition articles against a total number of 34 visuals published in The Hindu. Though Eenadu provided less space than The Hindu for coverage of nutrition related articles, but gave more number of visuals. Eenadu published 32 visuals along with a mere 13 reports on nutrition during the study period whereas, The Hindu published only 21 photos for the same number of articles. Similar trend was observed in health related visuals too. The Hindu published only 13 photos against 45 health reports, whereas Eenadu published 39 visuals along with 47 reports on health during the same period.

Table 1. Number of health and nutrition messages and space covered in the Newspapers during February 2010

\begin{tabular}{|c|c|c|c|c|c|c|c|c|c|c|c|}
\hline & \multirow[b]{2}{*}{$\begin{array}{l}\text { Total no. } \\
\text { of pages }\end{array}$} & \multirow[b]{2}{*}{$\begin{array}{l}\text { No. of } \\
\text { news } \\
\text { pages }\end{array}$} & \multirow[b]{2}{*}{$\begin{array}{l}\text { News Space (in } \\
\text { columns cms) }\end{array}$} & \multicolumn{4}{|c|}{ HEALTH } & \multicolumn{4}{|c|}{ NUTRITION } \\
\hline & & & & $\begin{array}{l}\text { No. of } \\
\text { news } \\
\text { repots }\end{array}$ & $\begin{array}{l}\text { No. of } \\
\text { visuals }\end{array}$ & $\begin{array}{c}\text { Space } \\
\text { (column } \\
\mathrm{cms} \text { ) }\end{array}$ & $\begin{array}{l}\% \text { of } \\
\text { Space }\end{array}$ & $\begin{array}{c}\text { No. of } \\
\text { news } \\
\text { reports }\end{array}$ & $\begin{array}{l}\text { No. of } \\
\text { visuals }\end{array}$ & $\begin{array}{c}\text { Space } \\
\text { (column } \\
\mathrm{cms} \text { ) }\end{array}$ & $\begin{array}{l}\% \text { of } \\
\text { Space }\end{array}$ \\
\hline The Hindu & 978 & 568 & $2,31,744$ & 45 & 13 & 2348 & 1.01 & 21 & 21 & 1528 & 0.67 \\
\hline Eenadu & 1178 & 767 & $2,29,500$ & 47 & 39 & 2965 & 1.29 & 13 & 32 & 729 & 0.32 \\
\hline Total & 2156 & 1335 & $4,61,244$ & 92 & 52 & 5313 & $2.30 \%$ & 34 & 53 & 2257 & $0.99 \%$ \\
\hline
\end{tabular}

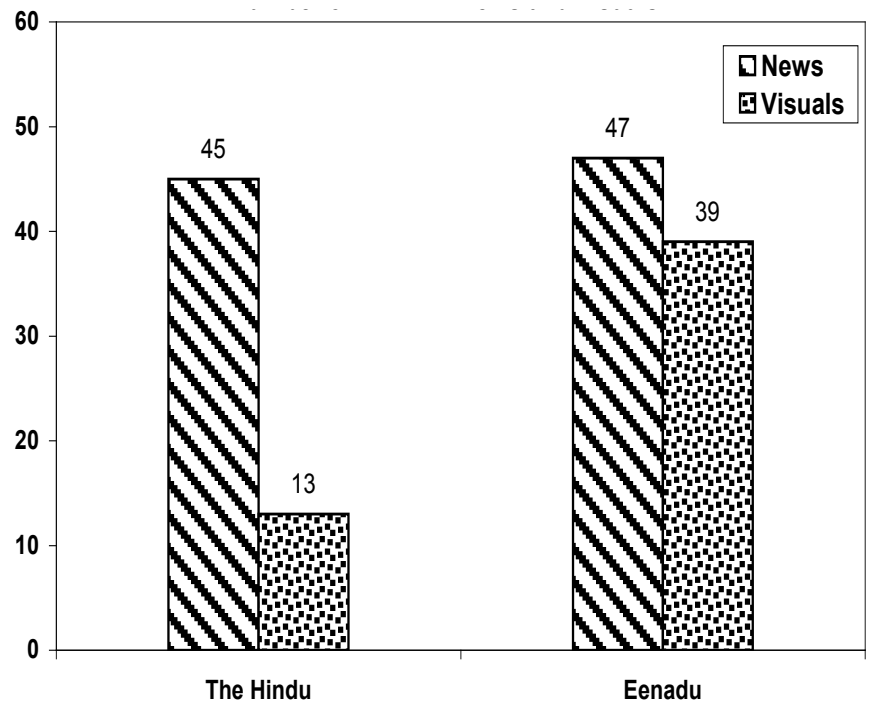

Figure 1. Comparison between The Hindu and Eenadu in coverage of number of HEALTH news and visuals

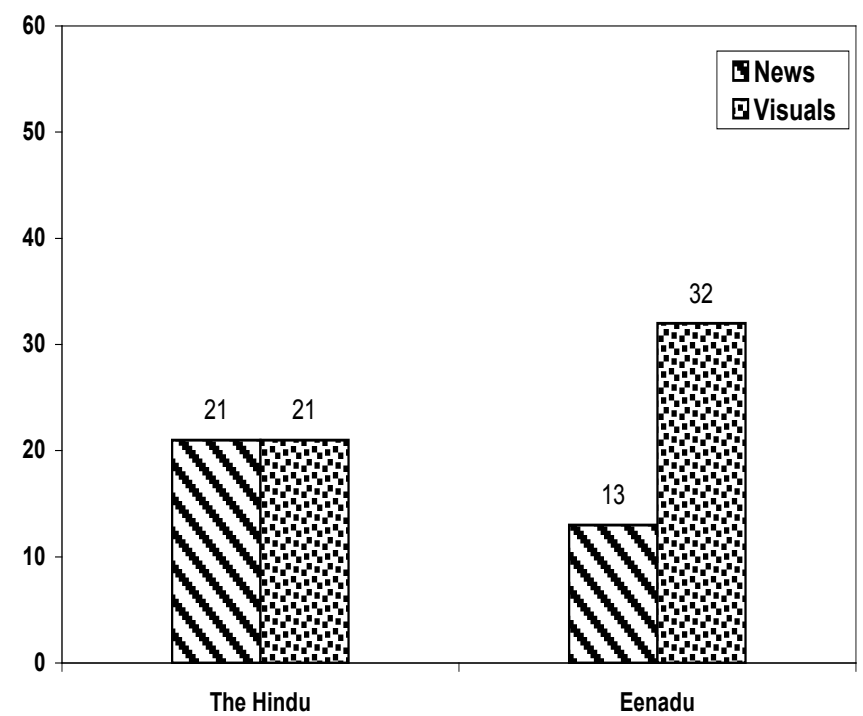

Figure 2. Comparison between The Hindu and Eenadu in coverage of number of NUTRITION news and visuals 


\section{Discussion}

Overall, The Hindu (English) and Eenadu (Telugu) newspapers gave decimal coverage for health and nutrition related news/ articles. India is a multi-lingual country, in which English and regional language newspapers too dominate in readership market[12]. Regional language newspapers are more popular among the readers of less educated with an economic background mostly consisting of lower and middle-income groups in rural and urban areas as well. At the same time, prevalence of overall undernutrition was also observed as higher among the lower[13,14] and middle-income[15,16] groups. On the other hand, English newspaper readers are mostly urban-centric with better socio-economic status than regional language newspaper readers. It was observed that prevalence of overweight and obesity is higher in urban than in rural areas[17].

\subsection{No Prominence to Health/ Nutrition News}

Eenadu, a popular regional language newspaper covered less number of nutrition related news/articles compared to English daily The Hindu. This trend indicates inadequate nutrition information to regional language readers who are economically backward and prone to undernutrition. Significant finding of the study was that, not a single news/ article on nutrition or health appeared on first page of either newspaper. One factor which is common to both language newspapers was, neither health nor nutrition news was covered regularly. Irregular coverage of nutrition subject was significantly observed in Eenadu. The period of gap for coverage of nutrition information in this vernacular daily ranges between two-to-seven days. During the study period, a gap of maximum eight days existed to appear atleast one report on nutrition in Eenadu. Almost same phenomenon was observed regarding health articles in this Telugu daily. Not a single news which gives atleast one or the other information about health appeared in Eenadu continuously for a period of five days.

\subsection{Lacks Regular Coverage}

The Hindu daily, though lacks regular coverage for nutrition and health articles, the period of gap was narrow when compared to its Telugu counter-part, Eenadu. A maximum of only two-day gap existed for coverage of health or nutrition articles in this newspaper. It shows that, The Hindu reader need not wait for more than two days to see one or the other item on health or nutrition. Most of the articles on health and nutrition were covered on stipulated days in Eenadu. For example, only on Tuesdays this daily covered more number of news and articles on the above topics. To be precise, this daily allotted special pages on health and nutrition on every Tuesday. Hence, out of total 47 articles on health and 13 articles on nutrition during the study period in this daily, 38 and 6 articles were appeared respectively on only Tuesdays.

Number of pages of a newspaper varies from day-to-day. For example, The Hindu consists of minimum number of 26 pages and Eenadu 36 pages on any ordinary day and maxi- mum 48 pages and 52 pages respectively on special occasions and festivals due to more number of advertisements. But, number of pages of the newspaper was not at all stood as criteria for publishing nutrition and health related reports. For instance, February $9^{\text {th }}$ dated The Hind $u$ consist maximum number of 44 pages, but not even single news on neither health nor nutrition was found on those pages. Eenadu too displayed the similar pattern.

\subsection{Meager Coverage in Supplement Pages}

Supplement pages of The Hindu and Eenadu were contrast in giving health and nutrition related articles. The Hindu supplements in tabloid form like Young World, Quest, Down Town has seldom contain nutrition news, whereas, Eenadu's supplement pages in tabloid form covered nutrition related information periodically. During the study period, only one article appeared in Editorial page of The Hindu and none in Eenadu. It is worthwhile to note, that Editorial page of newspapers particularly, The Hindu like dailies grabs attention of policy makers of the country. Hence, an article titled "Tackling the crisis of child malnutrition" in The Hindu's editorial page was most appreciable.

\section{Conclusions and Recommendations}

Indian print media's contribution in dissemination of health and nutrition information is meager.

$\bigcirc$ Quantity of health and nutrition information catered by regional language daily is less than the English newspaper.

$\bigcirc$ Regional language newspaper readers are mostly consist of economically backward and prone to undernutrition. This segment was not supplied with adequate amount of information on nutrition.

$\bigcirc$ More space need to be provided for educative articles on health and nutrition, particularly in regional language dailies..

Health and nutrition messages often need to be prioritized as page one reports.

$\bigcirc$ Regularity to be followed in publishing articles on health and nutrition in regional newspapers.

$\bigcirc$ Children need to be educated more on nutrition and food habits. Hence, special pages like Young World meant for children in The Hindu should consist one or other article on nutrition and food habits. These may also be in the form of cartoons, pictures, comics, paintings or in any other form which children love to read.

\section{REFERENCES}

[1] Fineberg HV, Rowe S (1998). Improving public understanding: Guidelines for communicating emerging science on nutrition, food safety and health. J Natl Cancer Inst. 90: 194-200.

[2] Borra ST, Earl R, Hogan EH (1998). Paucity of nutrition and 
Food safety 'news you can use' reveals opportunity for dietetics practitioners. J Am Diet Assoc. 98: 190-193.

[3] Houn F, Bober MA, Huerta EE, et al (1995). The Association between alcohol and breast cancer : popular press coverage of research. Am J Public Health. 85: 1082-1086.

[4] Begley A, Cardwell G (1996). The reliability and readability of nutrition information in Austarlian women's magazines. Aust J Nutr Diet; 53: 160-166.

[5] Smith R (1996). Three rules to cut the hype. British Med J. 312: 983.

[6] Frost K, Frank E (1997). Relative risk in the news media: a quantification of misrepresentation. Am J Public Health. 87: 842-845.

[7] Voelker R (1998). Getting the story straight on nutrition. J Am Med Assoc. 279: 417.

[8] Grill R, Ramsay C, Minozzi S (2005). Mass media interventions: Systematic review. Cochrane Database of Systematic Reviews. 1: 1-27.

[9] WAN (World Association of Newspapers) Report (2006).

[10] Mekam Maheshwar, Raghunatha D.Rao (2011). A comparative analysis of nutrition science coverage by popular Indian daily newspapers. J Media Commn Studies. 3(4): 131-143.

[11] Population Census of India (1992).

[12] ABC (Audit Bureau of Circulation) Periodical report: JulyDecember 2008.

[13] NNMB (National Nutrition Monitoring Bureau) Survey (2006). Diet \& Nutritional status of population and prevalence of hypertension among adults in rural areas. Published by National Institute of Nutrition, Indian Council of Medical Research.

[14] Basiotis PP, Carlson A, Gerrior SA, et al (2002). The Healthy Eating Index: 1999-2000. US Department of Agriculture, Centre for Nutrition Policy and Promotion. 2002. CNPP-12.

[15] James WPT, Nelson M, Leather S (1997). The contribution of nutrition to inequalities in health. British Med J. 314: 1545-1549.

[16] Davey Smith G, Brunner E. (1997). Socio-economic differentials in health: the role of nutrition. Proceedings of the Nutrition Society. 56: 75-90.

[17] Kaur S, Kapil U, Singh P (2005). Pattern of chronic diseases amongst adolescent obese children in developing countries. Curr Sci. 88: 1052-1056. 